\title{
数值制御工作機械の位置決め精度評価方法に関する研究*
}

\author{
神 崎 和 宏*1, 堤 正 臣*2, 陳 \\ 亮*3

\section{Evaluation Method of Accuracy of Positioning for CNC Machine Tools} \\ Kazuhiro KANZAKI, Masaomi TSUTSUMI and Liang CHEN

\begin{abstract}
It is very important to evaluate the positioning accuracy of $\mathrm{NC}$ machine tools, so that the evaluation method is standardized by ISO. It is, however, found from our experiments that two test cycles recommended by ISO gave different results, although only one permissible deviation is provided in the test code. In this study, the positioning accuracy has been precisely investigated, varying the test cycle, the feedback system and the feed rate of a machining center. From the experiments, it is found that the linear cycle gives larger deviation, which increases with the increase of the number of measurements, than the quasi-pilgrim step cycle. The increment of the deviation cannot be neglected in the quasi-pilgrim step cycle or the closed loop controlled system using a linear scale. Therefore, is it necessary to consider the thermal effect as well as the random and systematic errors when evaluating the positioning accuracy. Then, the effectiveness of an alternative method proposed in this paper is confirmed using several machining centers.
\end{abstract}

Key Words: Machine Tool, Machining Center, Positioning Accuracy, Repeatability, Test Cycle, Thermal Effect, Evaluation Method

\section{1. 粕言}

数値制御（N C）工作機械の位置決め精度は, I S O規格（IS0 230-2)(1)(2)に規定された方法に従って評 価することを原則としている．この規格は1972年に発 行された米国工作機械工業会規格が原案となって作成 されたものである(3).それから20年を経過した現在， この規格が高精度化したN C工作機械に適した評価方 法であるかどうかは疑問である.

1970年代の初めを振り返ってみると, 早送り速度, 最小設定単位の両方とも現在と 1 桁違っていた，標準 的な機械では, 早送り速度は $1 \mathrm{~m} / \mathrm{min} ら 2 \mathrm{~m} / \mathrm{min}$,

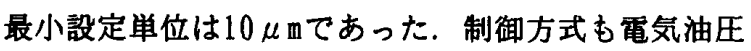
パルスモータを使ったオープンループ制御が主流で, 位置决め精度の偏差が士 1 パルス以内であっても $\pm 10 \mu \mathrm{m} の$ 時代である.

ところで，I S O規格の基本は，ひとつの目標位置 に一方向又は両方向から繰り返して位置決めしたとき の目標位置と㬰際の停止位贯との偏差をランダムな值

\footnotetext{
* 原稿受付 平成 4 年 7 月 15 日.

*1 学生周, 東京鹿工大学大学院 (184 小金井市中町 2-24-16).

*2 正員, 東京莀工大学工学部.

*3 東京麎工大学大学院.
}

と考えて，統計的に処理することである. しかし，著 者らは，数多くの位置決め精度の測定データをISO 規格に従って処理して行くうちに，偏差はランタムな ものでなく、テータ数が変わると最終的な評価結果が 変化してしまうことを見いだした。

そこで, 本論文では位置決め精度の評価結果は工作 精度に反映すると考え I S O 規格による位置决め精度 評価方法の問題点を明らかにし，従来まで偏差の主成 分として考えられてきた偶然偏差と系統偏差(3)に加え， 別途熱の影響を考虑するか，または熱の影留を極力小 さくする方法を考える必要のあることを明らかにする.

\section{2. 実殹方法}

$2 \cdot 1$ 位置決め精度の测定方法 実験対象として 立て形マシニングセンタ及びC N C 装置付 X Y テーブ ルを用いて，それぞれのY軸テーブルの位置決め精度 を，送り速度 $1 \mathrm{~m} / \mathrm{min} 及 ひ ゙ 20 \mathrm{~m} / \mathrm{min}$ ，分解能 $10 \mathrm{~nm}$ のレ ーザ干涉計を用いて測定した. その測定システムの概 要を図 1 に示す．実験に使用したマシニングセンタは， ロータリーエンコーダを用いたセミクローズドループ 制御を採用している.一方，XYテーブルのテーブル の位置のフィードバックは, マシニングセンタと同様 
のセミクロースドループ制御及びリニアスケールを用 いたクローズドループ制御の二通りが行えるように

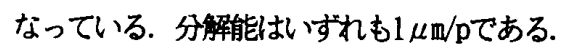

位置决め目標位置はY 軸の $0 \mathrm{~mm}, 80 \mathrm{~mm}, 160 \mathrm{~mm}, 240 \mathrm{~mm}$ $320 \mathrm{~mm}$ の計 5 点とした. ここで, 図2に示す I S O 規格 で定められた測定サイクルである直線サイクル及び折 返しサイクル(1)をY軸テーブルに行わせ，各目標位直 ごとに正方向と負方向から位置决めを行った，折返し サイクルとは，隣合った目標位圈の間で往復運動を行 い,それを連統する目標位置ごとに㮌番に稆り返す位 置決め遇動である．それに対し直線サイクルは各目標 位置を順番に通過し，機械の移動範囲全長に渡って往 復運動を繰り返す運動である。

$2 \cdot 2$ 策䉓対による温度测定 ボールねじの温度 上昇を直接測定するのが困難なためにXYテーブルの ボールねじのナットの温度上昇を測定した. その測定 には $\phi 0.3 \mathrm{~mm}$ の銅ーコンスタンタン線を用いた．測定 は, 架調された実験室内で，さらに萃置をビニールテ ントで覆い，雾囲気の温度変動を最小限にして行った。

\section{3. 荑検詰果及ひ考棎}

3.1 位置決め精度の変化 1 台のマシニングセ ンタの位置決め精度を, 送り速度を $1 \mathrm{~m} / \mathrm{min}$ 6 回の位置決めを行い，湘定した. 最初の 1 往復分を 除いて, 残りの 5 回分のテータを処理した結果を表 1 に示す.なお表中の記号はJISB6201（1990）に従った. 表に示したように，一方向䊅返し精度 $\mathrm{R} \uparrow ， \mathrm{R} \downarrow$ ，繰 返し精度 $\mathrm{R}$, 両方向位置决め精度 $\mathrm{A}$ ，反転偏差 $\overline{\mathrm{B}}$ の值 は全て, 直線サイクルの方が折返しサイクルよりも大 きくなっている. 他のマシニングセンタにおいても， これと同様の結果が得られることを確認している.こ

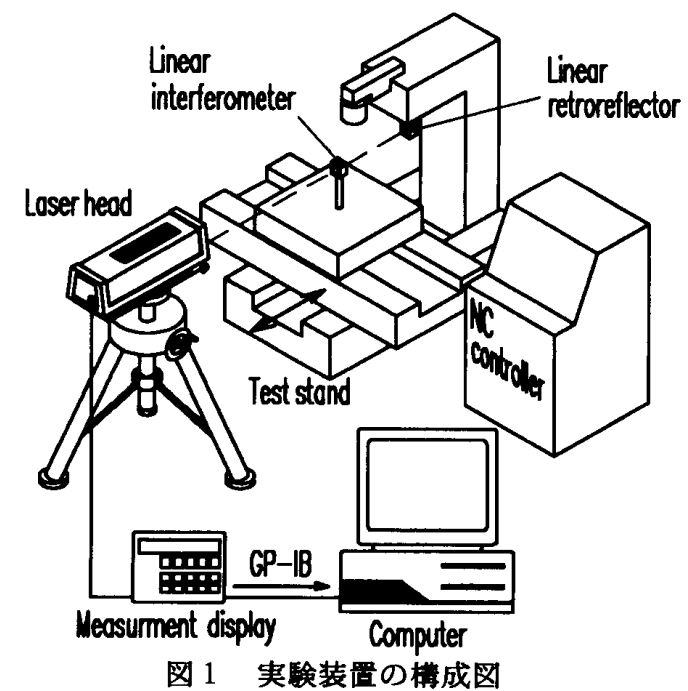

の原因を詳紻に調へるために，以下の実験は X Y テー ブルで行うことにした.

測定回数を增やすと偏差がどのように変化するのか を詳しく調べるために, 往復100回の位固決めを行な った．その結果の一例として，送り速度 $1 \mathrm{~m} / \mathrm{min}$, 目標 位置 $320 \mathrm{~mm}$ における測定回数と偏差との関係を図 3 に 示す. 図示したようにセミクロースドループ制御の場 合，偏差は直線的に增え，しかもその增え方は直線サ イクルの方が折返しサイクルよりもかなり大きくなっ ている.

テーブルの位圈の検出をリニアスケールで行ない同 様の実験を行なった結果も，図4に示すように直線サ イクルと折返しサイクルとは一致せず，直線サイクル 及び折返しサイクルの両方においては偏差に増分を生 じているのがわかる.このような図 3 及び図 4 に示し た偏差の增分の差が原因となって, 表 1 に示した直線 サイクル及び折返しサイクルの位置決め精度及び繰返 し精度の評価結果に差が生じたことになる.

偏差の增加の著しい直線サイクルの各目標位置にお ける測定結果を順番に並へると，結果を示していない か, 偏差の增分はボールねじが伸びる方向である支持

表 1 直線サイクル及び折返しサイクルの位置決め精 度の比較（実機：A）

\begin{tabular}{c|ccccc}
\hline & $\mathrm{R} \uparrow$ & $\mathrm{R} \downarrow$ & $\mathrm{R}$ & $\mathrm{A}$ & $\mathrm{B}$ \\
\hline Quosi pilgrim step cycle & 0.66 & 0.78 & 8.09 & 8.53 & 5.53 \\
Lineor cycle & 3.48 & 2.04 & 9.85 & 10.29 & 7.50 \\
\hline $\mathrm{R} \uparrow, \mathrm{R \downarrow}$ : Unidirectional & $\mathrm{R}:$ Bidirectional \\
A: Accurocy & \multicolumn{3}{c}{$\mathrm{B}:$ Meon reversal value }
\end{tabular}

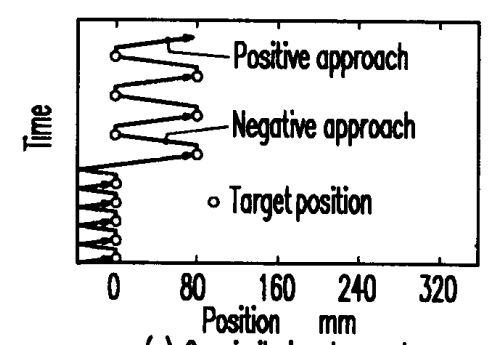

(a) Quosi pilgrim step cycle

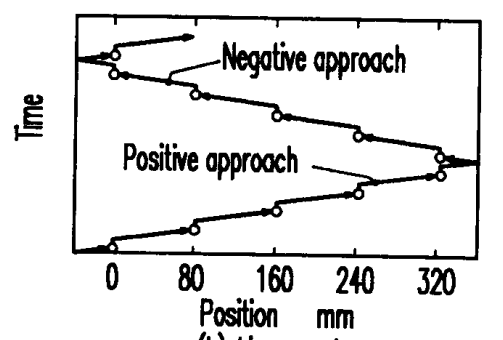

(b) Linearcycle

図 2 直線サイクル及び折返しサイクル 
端寄りの方がきくなることがわかっている。これは 折返しサイクルの場合も同様の結果であった.

偏差がこのように変化する原因は，サーボモータの 発熱, ナットやベアリングにおける相対運動による摩 摖熱などによって，ボールねじが徐々に支持端寄りに 熱膨張していることが考えられる(4) (6). またリニア スケールの検出ヘッドの相対運動による摩撚熱による 熱膨張, 及びテーブルの熱膨張によるリニアスケール の伸びも原因として考えられるか，この詳細について は別途検討することにしたい，

3.2 ボールねじの熱谑張の影鱼 ボールねじの 熱膨張の影響を調べるために，送り速度を $20 \mathrm{~m} / \mathrm{min}$ し, 送り速度1⿴囗m/minのときの結果と比較した，七ミク

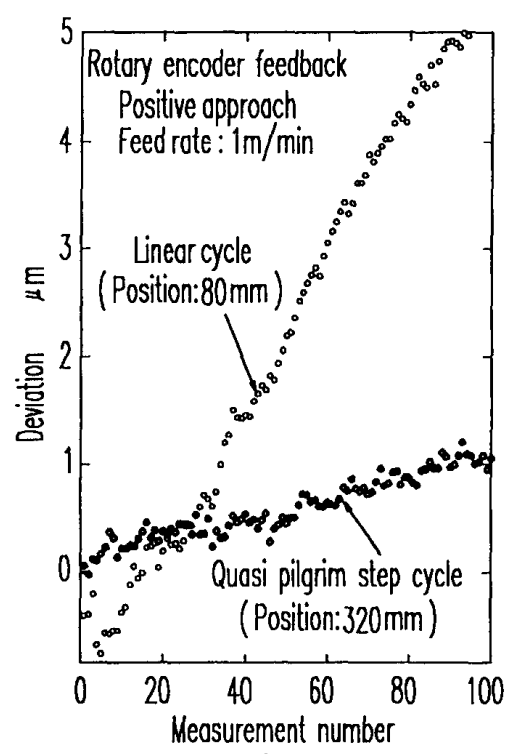

図 3 セミクローズドループ制御の場合の測定回数と 位置決媥差との関係

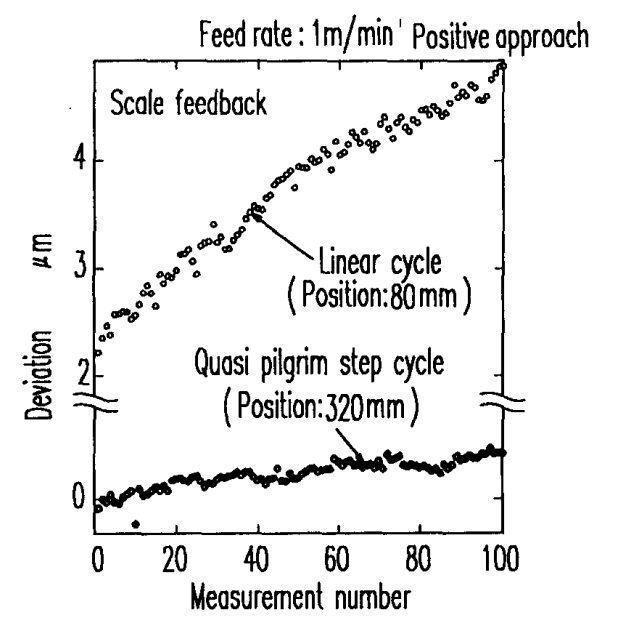

図4 クローズドループ制御の場合の測定回数之位置 決め偏差との関係
ローズドループ制御方式では，偏差の增分がほぼ一定 であるので，測定回数を 20 回とした，その結果を図 5 に示す，図によると直線サイクル，折返しサイクル共 に送り速度 $20 \mathrm{~m} / \mathrm{min}$ 方方偏差の增分が大きいことが わかる．これは送り速度を速くすることにより，サー ボモータの発熱, ボール枦じとナット又は軸受との相 対運動による摩摖熱によってボールねじが伸びたため と考えられる.

そこで，ボール好じ温度上昇を調へるために図 6 に示すようにナットの表面に熱電対を溶着し，往復100 回の位置決めを行い温度上昇を測定した，その之きの 結果を直線サイクルと折返しサイクルとに分けて示す と，それぞれ図 7 及び図 8 のようになる．測定時の室 温の変動は図 7 (a)及び図 8 (a)に示すように最大でま

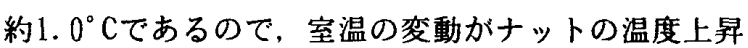
に及ぼす影響は少ないと考えられる．図7 (b)及び図 8 (b)によると，送り速度が $20 \mathrm{~m} / \mathrm{min}$ のときの方が ナット表面の温度上昇が大きいこと, また折返しサイ クルの方が温度上昇は大きいことがわかる。

このように, 測定回数の増加とともにナットの温度 が上昇していること, また送り速度 $20 \mathrm{~m} /$ minの方が, $1 \mathrm{~m} / \mathrm{min}$ の場合よりも温度上昇が大きいことから，ボー

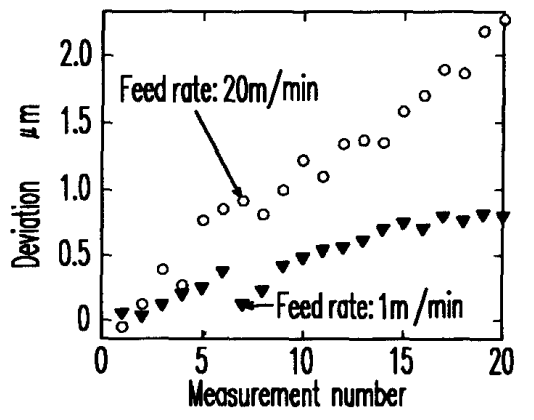

(o) Lineor cycle

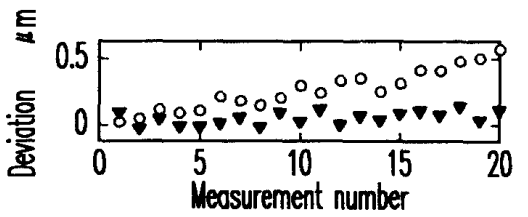

(b) Quosi pilgrim step cycle

図 5 位置決め偏差に及ぼす送り速度の影響(目標位置: $80 \mathrm{~mm}$, 負方向位置決め,セミクローズド制御）

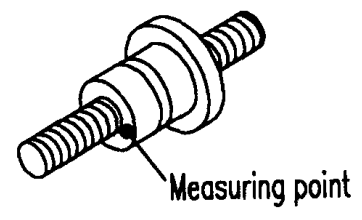

図 6 熱電対溶着点 
ルねじが熱膨張した結果，セミクローズドループ制御 の場合にはより大きな偏差を生じたと考えられる。

なお折返しサイクルの方が直線サイクルよりもナッ トの温度上昇が幾分大きく現れているが，折返しサイ クルではボールねじが短い区間で往復運動を行うので， ボールねじの自然冷却効果が小さいため局所的に温度 が高くなっていると考えられるが，この点についても 今後検討したい.

そこで図 3 及び図 4 の直線サイクルの熱の影響を直 線とみなして，最小自乗法によって補正してランタム 偏差だけを抽出した．その結果を図 $9 に$ 示す．標準偏 差の推定値 $\pm 3 \mathrm{~s}$ の幅 $6 \mathrm{~s}$ 求めると，その幅はセミクロ

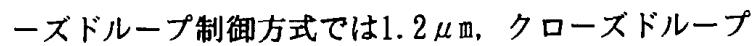
制御方式では $0.8 \mu$ 它なった。これらの值は制御系の 分解能である $1 \mu \mathrm{m}$ とほぼ一致するので，高精度な位置 決めが実現されていると言える. 送り速度 $20 \mathrm{~m} / \mathrm{min} の$ 場合も，測定回数は20回であるが，幅6sは $0.7 \mu \mathrm{m}$ とな りほぼ同様の結果になった。

どの目標位置においても偏差が一方向に増えたり 隇ったりするのならば,ここに示したような直線近似 をして偏差を補正すればよいが, 次章で述べるように， 必ずしも同じように扱えるとは限らないのて，熱の影 整があり強く出ない評価方法について次章で検討す ることにする.

$3 \cdot 3$ 位蜀決め精度の評価方法の問通点 以上述 へたように，I S O 規格に従った位置決め精度の評価 結果には，測定サイクルによる違いがあり，測定回数 によっても変わることがわかった．これは，I S O 規 格では位置決め精度の偏差の成分を偶然偏差と系統偏

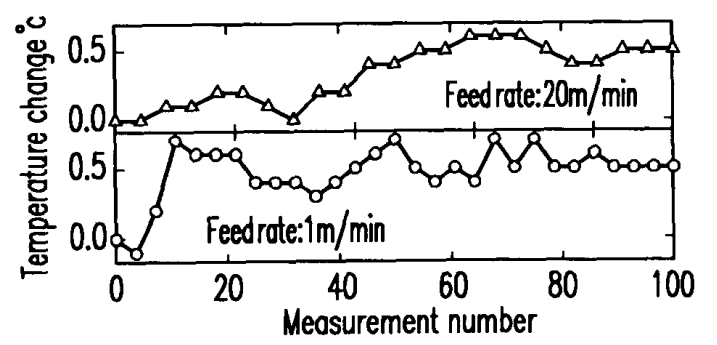

(o) Temperature change of room

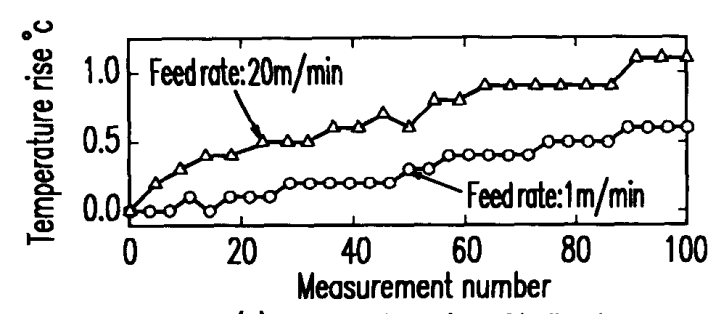

(b) Temperature rise of ball nut

図 7 直線サイクルの場合のナットの温度上昇
差とに大別し，統計的にテータを処理する方法を採用 していることと関係している.

測定回数が增えるに従って一方向に偏差が増えたり 堿ったりする場合には，I S O規格に示す方法に基つ いて精度を評価しても意味があるとは考えられない． 重要なことは偏差がどのように変化するのかを知るこ とである，例えば 1 個目の部品と $\mathrm{n}$ 個目の部品の精度 の違いを予測できるテータを提供する方がより重要に なることもあれば，1個の部品に複数の穴をあけるよ うな場合には, 穴間の距離寸法の偏差がどの程度であ るかを知ることも重要である．また工作機械を設計す る上でも偏差の増減の傾向を知ることは重要である. 従って, 従来の偶然偏差と系統偏差に加えて, 偏差の 変化傾向を新たに考虑する必要があると考えられる。

\section{4. 目模位䍡間距襍后差による評洒}

以上の結果から，熱の影製が位置決め精度の評価結

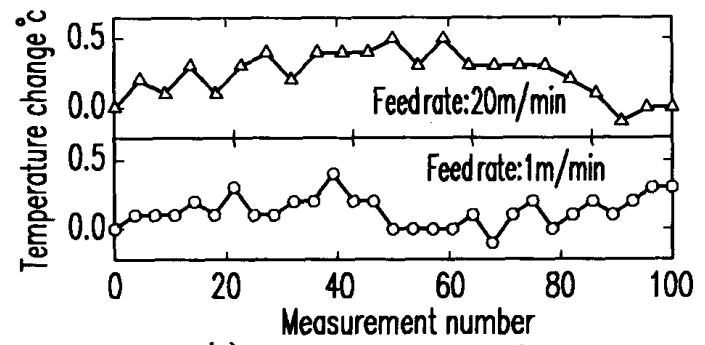

(a) Temperature change of room

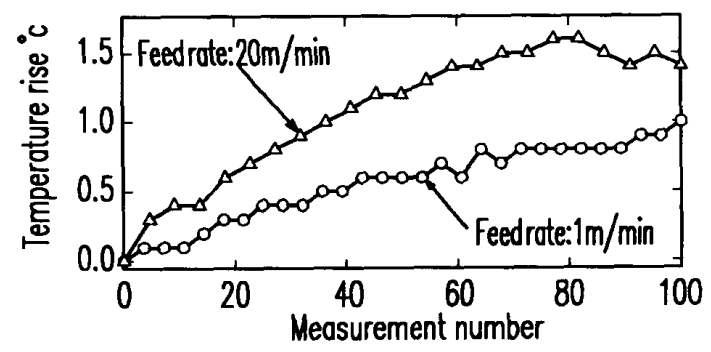

(b) Temperature rise of boll nut

図 8 折返しサイクルの場合のナットの温度上昇

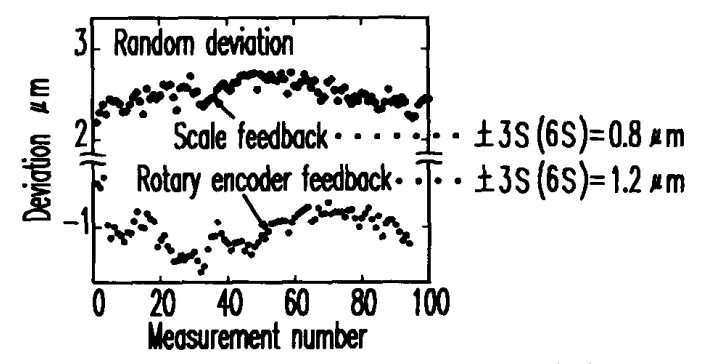

図 9 熱の影部を補正したときの位置决め偏差(直線サイクル， 目標位置: $80 \mathrm{~mm}$ 正方向位置决め, 送り速度 $1 \mathrm{~m} / \mathrm{min}$ ) 
果に大きな影製を及ぼすことがわかった．位置決め偏 差が熱の影響を受けてどのように変化するのかを知る には，測定回数を增やして，その結果を各目標位置毎 に単純に並べれば良い，しかしこれでは手間と時間が かかってしまう，従って，従来どおりの少ない測定回 数で，しかも熱の影響ができるだけ少ない状態で位置 決め精度を評価できる方法が必要である.

ここで新な評価方法を検討することにした．式(1) に示すように，隣合う目標位置の同一測定回数におけ る差を取り，それらの值から土 $3 \mathrm{~s}(6 \mathrm{~s})$ を求めれば， ボールねじの伸び及びリニアスケールの伸びの影響が ほとんど入らない状態で評価できると考えられる．ま た，式(1)のような処理をすることによって，1個の 部品に複数の穴をあけた場合の穴間距離寸法の誤差も 推定できることになる.

$$
\begin{gathered}
x_{(1-k), i}=x_{i i}-x_{k i} \quad \cdots \\
\text { ただし } k=j+1
\end{gathered}
$$

式(1)はj番目及びk番目の目標位置のi回目の測定値の 差を表す。この方法を図10(a)，図11(a)及び図12(a) に示す測定結果に適用することにした。これらは，製

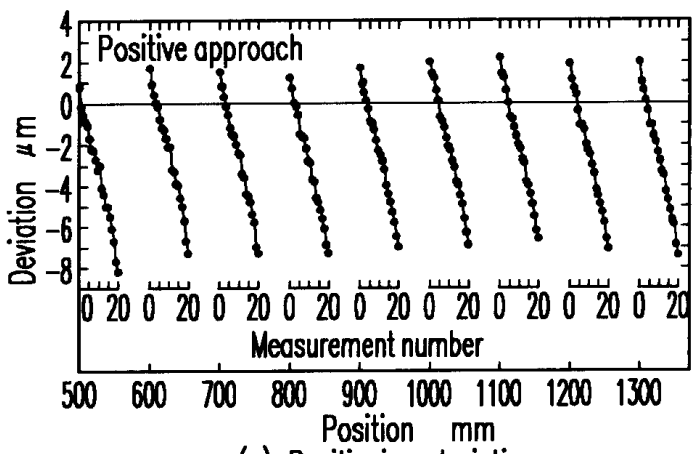

(a) Positioning deviation

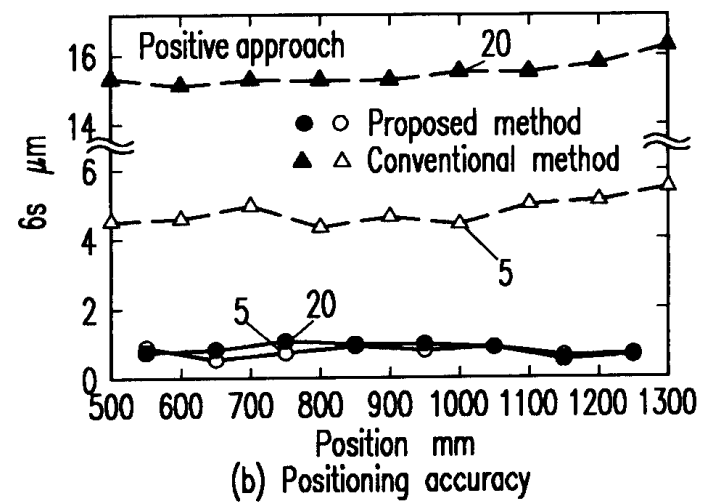

図10提案した評価方法と従来の評価方法との比較 （実機Bの場合）（早送り速度 : $20 \mathrm{~m} / \mathrm{min}$ ）
造メ一力の異なる約 10 機種の測定結果から, 代表的な 3つのパターンを選んだものである．パターン(1)は， 図10(a)に示すように，各目標位圈における测定結果 の增分が直線的でほぼ同じ場合で図 5 に示したX Y テープルと同じような場合，パターン(2)は，図11(a) に示すように，各目標位置における增分が徐々に変化 して, 增减の方向が逆転する場合，そしてパターン(3) は, 図12(a)に示すように偶然偏差の成分が大きく増 隇の方向が明確でない場合である，それぞれの図に測 定回数を5回之20回とした場合について式(1)による方 法と従来のIS Oの方法とによって求めた $6 \mathrm{~s}$ の値を示 してある.

I S Oの方法では, 図10, 図11及び図12に示したよ うに, いずれのパターンでも測定回数が5回と20回と を比較すると，ほとんどの場合に20回の方が6sが大き

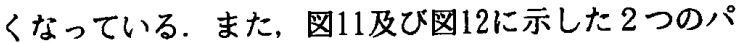
ターンの場合には，各目標位置における6sに大きな差

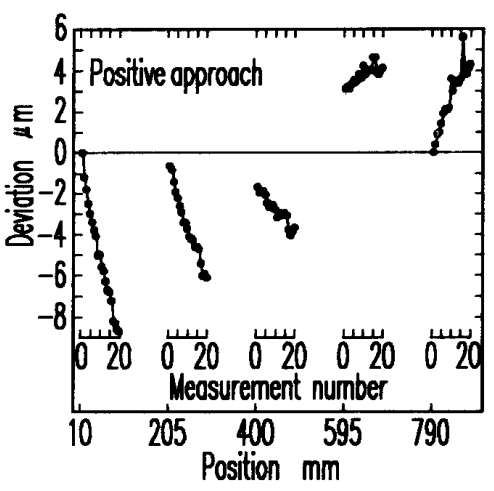

(a) Positioning deviotion

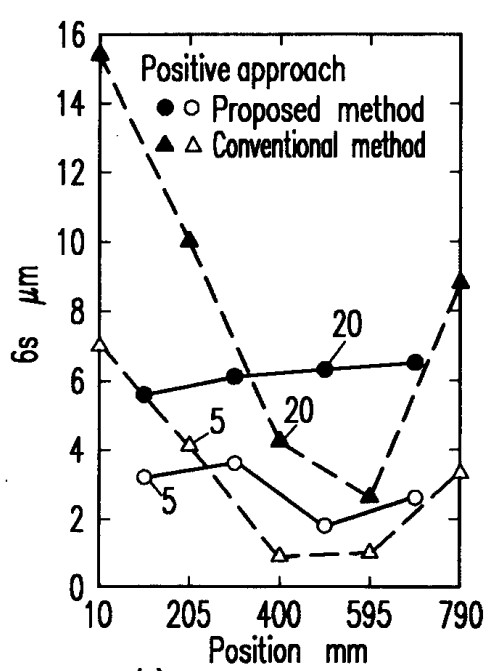

(b) Positioning accuracy

図11提案した評価方法と従来の評価方法との比較 （実機 Cの場合）（早送り速度 : $20 \mathrm{~m} / \mathrm{min}$ ） 

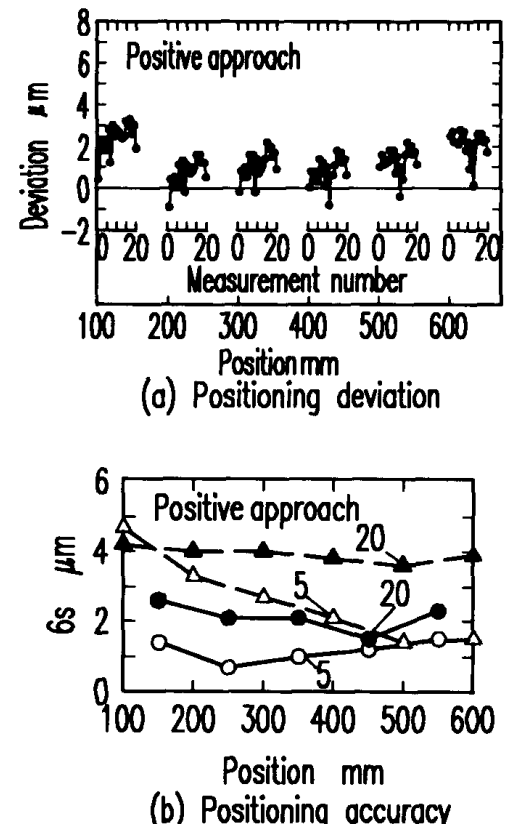

図12 提案した評価方法と従来の評価方法との比較 （実機Dの場合）（早送り速度: $20 \mathrm{~m} / \mathrm{min}$ ）

が認められる.

これに対して，式(1)による目標位㯰間距離偏差に よる方法では，図10に示すようにパターン(1)場合は， 測定回数による差がほとんどなく，また図11及び図12 に示すパターン(2)及びパターン(3)の場合は回数による 差はあるものの, 目標位固間の差は少ない.

さらに詳細にこれらの図をみると，式(1)によって 偏差を求める方法で測定回数の影篅を取り除くこと はできないが, パターン(1)のように定方向に偏差が 增加するものでは6sか小さく評価され，1 $1 \mu \mathrm{m}$ 程度と なってエンコーダの分解能の範囲になっている．偏差 の增減の方向が逆転するパターン(2)で6sはパターン (1)よりも大きくなり，エンコータの分解能以上の值に なる，そしてもともと不規則な変化をするパターン(3) では従来の方法とほぼ同し大きさとなる測定位置であ り、パターン(1)や゚ターン(2)ほどの差はない.

このように式(1)による方法は, 測定回数による評 価結果の差をなくすことはできないか，従来の方法に
比へてその差を小さくでることから，次善の方法て あると言える.

\section{5. 诘 言}

I S O 規格による位置決め精度の評価方法を用いて， 実際に評価を行った結果,

(1)測定サイクルの遑いによって評価結果に差がで ること。

(2)測定回数によっても差がでること， から， I S O 規格に規定されている評価方法には問題 があることがわかった．この原因について調へたとこ ろ，セミクローズドループ制御だけでなく，クローズ ドループ制御でも同様の傾向が見られたことから、ボ ールねじの熱膨張のみならずリニアスケールの伸びも 関係していると推定され，より高精度に位置決め精度 を評価するには，熱の影翠を考虑しなければならない ことがわかった。

次に，実際の機械加工を考えて，できるだけ熱の影 製を小さくするような評価方法を提案し，実機による 測定結果を用いて検討したところ，测定回数による差 を小さくできることがわかった。

\section{春考文献}

(1) ISO 230-2: Acceptance code for machine tools-Part2: Determination of accuracy and repeatability of positioning of numerically controlled machine tools, (1988).

（2）JIS B 6201，工作機棫一就䮦方法通則，日本規格協会， (1990).

(3) ANSI/ASME B5.54.1991(D), Methods for performance evaluation of computer numerically controlled machining centers, (1991).

（4）大塚二郎・深田茂生・小朔信夫，ボールねしの熱麃張に関す 万研究（定予压の堨合），精密機械，50-4，(1984），646-651

（5）山口利明・武内垣衣，ボールねじを用いた精密位置决め技術, 応用機械工学，32-1，(1991)，109-115

（6）二宮瑞搮，ボールねしの発熱と対応策，応用機械工学，28-4, (1987), 98-103 